\title{
The Impact of Encroachment on the Distribution of Tree Species in Cross River National Park, Oban Division, Nigeria
}

\author{
Margaret A. Yaro \\ Department of Urban and Regional Planning, Cross River University of Technology, Calabar, Nigeria \\ Email: mamboline2004@yahoo.com
}

Received 14 March 2015; accepted 25 July 2015; published 28 July 2015

Copyright (C) 2015 by author and Scientific Research Publishing Inc. This work is licensed under the Creative Commons Attribution International License (CC BY). http://creativecommons.org/licenses/by/4.0/ cC) (7) Open Access

\begin{abstract}
Increasing human activities around protected area pinpoint to looming degradation and alteration of the component of such areas, especially where adequate measures are not taken to forestall encroachment. The Oban division of the Cross River National Park is one of the oldest rainforests and has been identified as a biodiversity hotspot. However, communities settling around the park have been involved in some economic activities for their livelihood. Resource utilization at the edge of the park may alter the components of the park such as species diversity. Therefore this study is geared towards assessing the impact of human encroachment and the concomitant impact on the distribution of species within the park. The study adopted participatory research methods which included Focus Group Discussion and participatory mapping as well as a plot based survey which involved the laying of sample plots within two zones of the park designated as areas bounded by cultivated land and areas bounded by fallow. Three $40 \mathrm{~m} \times 40 \mathrm{~m}$ square plots are laid along a 320 meter transect measured from the boundary of the park at each buffer zone. The plots are separated by $100 \mathrm{~m}$ gap. From the result obtained, it is discovered that Musanga cercropoides dominates the outer plots of the cultivated zones and fallow zones comprising 20.2 and 21.5 percent respectively while Terminalia ivorensis dominates the middle and inner areas of the park. Moreover the composition of species decreases inward to the inner part of the park. Diversity index decreases in the order of $2.566<2.348<2.163$ at the cultivated zones and $2.443<2.376<2.366$ at the fallow zones. It is concluded that human activities close to the park alters the species composition of the park. Hence, it's recommended that adequate alternatives livelihood and incentive be provided to support zone communities to reduce their dependents on the edge of the park.
\end{abstract}

\section{Keywords}

Park, Encroachment, Impact, Diversity, Colonizers, Zones 


\section{Background to the Study}

One of the conservation strategies adopted in many countries in the world is the Protected Area System (PAS). Protected areas are areas of land and/or sea exclusively dedicated to the protection and maintenance of biological diversity, natural and associated cultural resources which are managed through legal or other effective means (IUCN in [1]) [2]. The Convention on Biological Diversity (1992) describes a protected area as a geographically defined area, which is designated or regulated and managed to achieve specific conservation objective [3]. Protected areas include the parks, reserves, strict nature reserves, wilderness among others. Globally, PAS arises out of the need to curtail the loss and degradation of biodiversity. IUCN has captured protected area categories and designated those areas and species that require adequate attention [4]. The most serious problem behind PAS is habitat loss around the edges of forest and other protected areas caused largely by the expansion of agriculture [5] [6]. The pressure on biodiversity continues to increase decline, with substantial and ongoing losses of populations, species and habitats despite the adoption of PAS. Loss of biological diversity includes the loss of habitats, the introduction of exotic species, over-harvesting of biodiversity resources, and homogenization of species in agriculture.

Forest loss in Africa is particularly troubling because one-third of the continent's population depends on forest resources resulting in deforestation which is estimated at about 3.4 million hectares per year [6]. In the last decade, deforestation and biodiversity loss has become a common event throughout the world. This phenomenon is much more frequent in rural areas of developing countries. Many forest trees are also used for fuel and charcoal which constitute sources of heat energy for small scale processing enterprises such as bakery, palm oil production and fish smoking. Others are used as browsing leaves for animals, household utensils and farm implement handle. However, the high degree of utilization of these resources by the communities critically threatens the livelihood and biodiversity across the country [6] [7].

Cross River National Park like most African National Protected Areas, was created in 1991 with the sole aim of conserving the last remnant of the Cross River Tropical Rain Forest from extinction, while at the same time, improving the livelihood of the forest communities [8] [9]. The Park has one of the oldest rainforests in Africa, and has been identified as a biodiversity hotspot. Its concept involves the exclusion of people from wildlife areas apart from visitors and employees concerned with its management [10]. The Park is rich and unique in its forest resources of plants and animal species.

Although the Park conserves many of the world's habitats and species, human encroachment is severely degrading and destroying the biodiversity of the area. This has often resulted in the elimination of species, loss of forest lands and resources. Destruction of wildlife habitats has remained the leading threat to biodiversity. This destruction, takes different forms such as degradation, fragmentation or outright loss, and is a function of the growing human population and activities prompted mainly by such factors as poverty, demography, land tenure systems, inadequate conservation status, development policies and economic incentives [10]. These factors range in scale from immediate to global.

Forest encroachment is a term used to describe the "use and cultivation of forest land by local population without proper legal entitlement over such land". The major cause of this encroachment is the increasing population of the people, "it is an obvious fact that population grows at geometrical rate while food production grows at arithmetical rate according to Malthus Theory” [11]. Population has been a chief agent of environmental degradation in most cities of the world.

Since the creation of the park, many communities and researchers on livelihood have faulted that protected areas have deprived local people of resources which they have been depending on over the years for both cultural and economic reasons [6] [7]. The reason behind this is the restrictions of the people from utilizing the forest products for their livelihood. This has often resulted in conflict and forceful entrance into the park. Sometimes the people carry out some activities at the buffer zone and encroach into the park from time to time. The fact remains that the cumulative impact can result in loss of species.

Forest encroachment is one major challenge in Cross River National Park and other forest communities of Cross River State, Nigeria. This encroachment takes various forms such as human settlement, farming, hunting, fishing, collection of non-timber forest resources (NTFR), grazing, clearing and cutting down of trees and so on. Illegal forest clearing, poaching, and failure to respect timber-harvesting regulations have depleted the natural resources and caused serious environmental problems. These activities have also negatively affected the environmental services which are important to poor rural households such as the provision of clean water, pest and 
disease control, pollination, and regulation of the climate, stream flow, and groundwater levels.

The common factor of all these elements is that they are human-driven. It is necessary to probe how human activities have encroached on the park, hence are species composition and diversity the same everywhere around the park? This research therefore seeks to examine the activities of encroachment and potential impacts on biodiversity vis-à-vis species distribution and diversity within the different areas of the Cross River National Park, Oban Division, Nigeria.

\section{Study Area}

The Cross River National Park is located between latitude $5^{\circ} 05^{\prime}$ and $6^{\circ} 29^{\prime} \mathrm{N}$ and Longitude $8^{\circ} 15^{\prime}$ and $9^{\circ} 30^{\prime} \mathrm{E}$, in the Southeastern corners of Nigeria. It covers a total of about $4000 \mathrm{~km}^{2}$, most of which consist of the coastal zones (Figure 1).

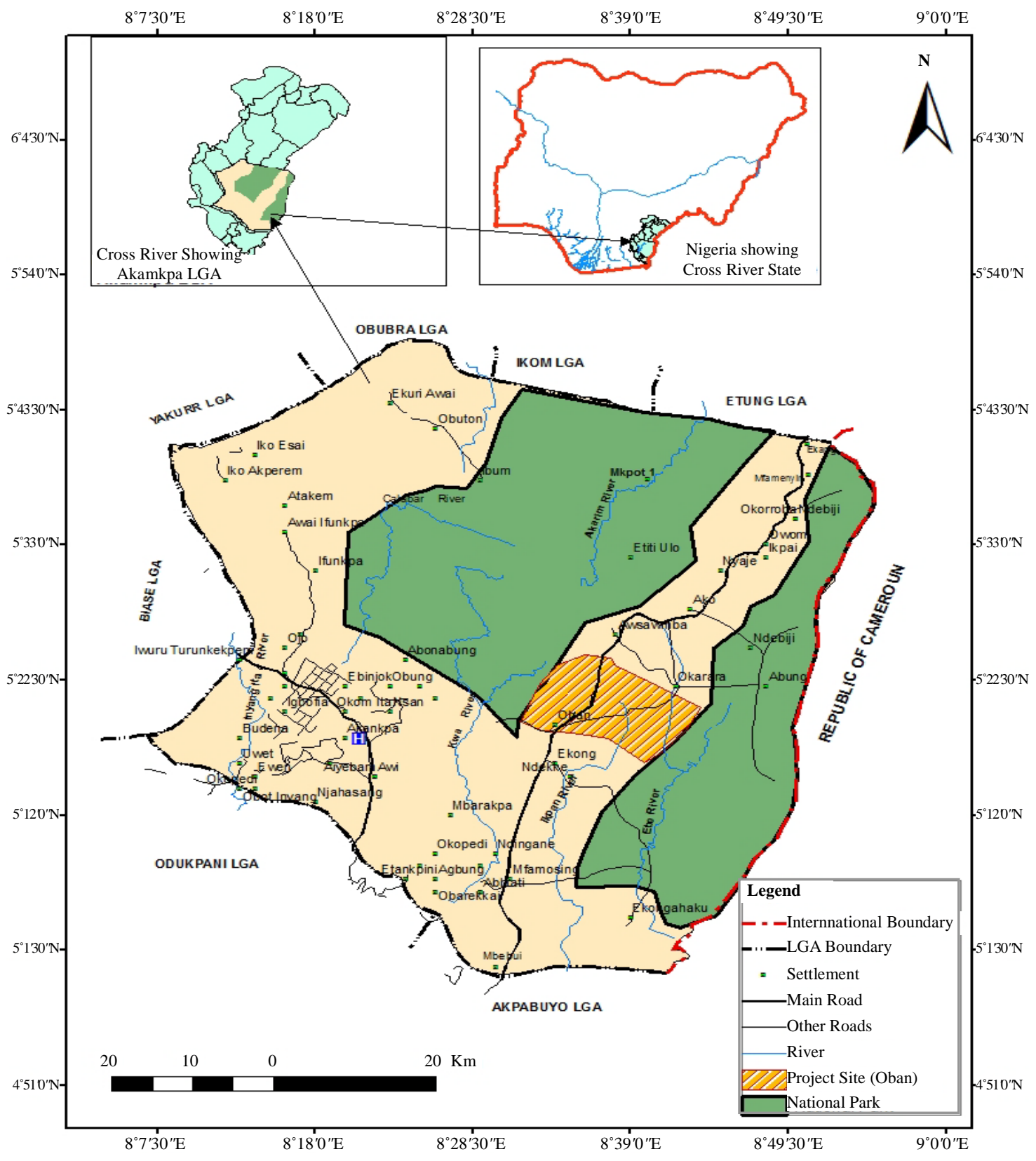

Figure 1. The study area. Source: Adapted cross river state ministry of lands and survey map (2013). 
The climate is a tropical humid one [12]. Annual rainfall ranges between $2500 \mathrm{~mm}$ and $3000 \mathrm{~mm}$. The rainy season lasts from March to November, the temperature ranges from $25^{\circ} \mathrm{C}$ to $27^{\circ} \mathrm{C}$ in January, but in July, it rises above $30^{\circ} \mathrm{C}$. Relative humidity is about $75 \%$ to $95 \%$ in January, but towards the end of the year, it lowers gradually as a result of harmattan [12].

The vegetation of the area is evergreen tropical rainforest, and it is regarded as the last stronghold of tropical rainforest in Nigeria [13]. The terrain is rough and elevation rises from the river valleys to cover $1000 \mathrm{~m}$ in the mountainous areas. The soils are ferralitic and sandy, and steadily become shallower with increasing elevation. The soil is highly vulnerable to leaching and erosion where stripped of plant cover.

The Park is noted for its high diversity of species but in spite of its great diversity and richness, the area is prone to degradation through human activities ranging from hunting and poaching, agriculture, logging to unguided exploitation of Non-timber Forests Products (NTFPs). Typical tree species found there includes Belinia confusa, Coula edulis, Hannoa klaineana, among others. There are about 1568 plant species, of which 77 are endemic to Nigeria. There are at least 75 mammal species, including Africa buffalo, the endangered Afri- can forest elephant, common chimpanzee, 42 species of snakes.

\section{Methodology}

This research adopts a mix of methods for data collection. The methods include sample plots, inventory, and selected Participatory Rural Appraisal (PRA) tools such as Focused Group Discussion (FGD), transact walk, key informants interviews and observation etc.

A transact walk was taken through the park with the assistance of key informant to identify the different activities, changes in the area and observed pattern of features within the park. This enabled the researcher to categorize the area surrounding the park into two, viz areas bounded by farmlands and areas bounded by fallow.

A transect of $320 \mathrm{~m}$ was measured from the beginning of the park and $40 \times 40 \mathrm{~m}^{2}$ sample plots were laid across the transect at the beginning, in the middle and at the end from the buffer zone to the inner part of the park. The plots were separated by a distance of 100 meters. The plots were laid with the assistance of four local forest resource users in the study area and a taxonomist. A hand held compass was used in establishing the diagonals of $28 \mathrm{~m}$ from the center of the plots to join the edges forming $40 \mathrm{~m}^{2}$. Two areas were considered in laying the sample plots which included the areas bounded by farms (cultivated area) and the areas bounded by fallows of 5 years and above (secondary regrowth). Three sample plots were laid in each area which gave a total of six plots. Measurement of individual trees was carried out for all trees not below $5 \mathrm{~cm}$ in diameter. The trees were counted and measured at $1.3 \mathrm{~m}$ above ground with a tape.

Key informant interviews were used to elicit information from the people on the types of activities going on within the buffer zones of the park as well as the species that are mostly utilized. Moreover, a Focus Group Discussion was held with the different resource user groups on the nature of their activities and then triangulation was carried out to ascertain how their activities impinge on the Park.

Analysis was carried out using simple percentage and Shannon weiner diversity index

The index is given as: $H_{1}=\sum_{i=1}^{S} p_{1} \log _{e} P(i)$

where:

$H_{1}=$ Value of Shannon Wiener diversity;

$S=$ No. of species in the community (taken as sample plot);

$P_{i}=$ the properties of species;

$\log _{e}=$ Natural logarithm of $P(i)$.

\section{Result}

\subsection{Activities of Resource Users and Their Impact on the Forest}

Various forms of activities were identified from the FGD conducted to ascertain the ones that led to the encroachment and their impacts on the Park. Many support zone communities living close to the park encroach on the Park for their livelihood; there are also negative impacts of these activities on the Park resources. Table 1 summarizes the types of activities, indicators of encroachment and the likely impact on the forest. 
Table 1. Activities of resource users and their impact on the park.

\begin{tabular}{|c|c|c|c|}
\hline $\mathrm{S} / \mathrm{n}$ & Types of Activity & Indicators & Impact on Forest \\
\hline 1. & Farming & $\begin{array}{l}\text { - } \text { Creation of small plantation } \\
\text { - Creation of Cocoa farm } \\
\text { - } \text { Planting of food crops }\end{array}$ & $\begin{array}{l}\text { - } \text { Change in Land use } \\
\text { - Habitat fragmentation } \\
\text { - Restriction of Animals and Birds movement } \\
\text { - Habitat destruction } \\
\text { - Migration of animal population } \\
\text { - Soil erosion }\end{array}$ \\
\hline 2. & Hunting & $\begin{array}{l}\text { - Wire traps/nets } \\
\text { - Digging and burning of holes } \\
\text { - Collection of eggs from nest }\end{array}$ & $\begin{array}{l}\text { - } \text { Killing of birds and animals } \\
\text { - } \text { Marks of gun shots on trees } \\
\text { - } \text { Migration of wildlife population } \\
\text { - } \quad \text { Noise }\end{array}$ \\
\hline & & $\begin{array}{l}\text { - Building and construction of temporal huts } \\
\text { and sheds made with raffia and bamboo } \\
\text { - Living in Caves }\end{array}$ & $\begin{array}{l}\text { - Habitat fragmentation } \\
\text { - Restriction of animals and birds movement in the wild } \\
\text { - Creation of fear }\end{array}$ \\
\hline 3. & $\begin{array}{l}\text { Collection of } \\
\text { Non-Timber Forest } \\
\text { Products (NTFPs) }\end{array}$ & $\begin{array}{l}\text { - } \text { Cutting of Capolopia } \\
\text { - } \text { Breaking of Sapling } \\
\text { - } \text { Debarking of trees } \\
\text { - Cutting Randia } \\
\text { - Gallection of leaves and herbs } \\
\end{array}$ & $\begin{array}{l}\text { - } \text { Competition of food } \\
\text { - Habitat destruction } \\
\text { - Sood shortage } \\
\text { - } \text { Soil erosion } \\
\text { - } \text { Migration of birds and animals } \\
\end{array}$ \\
\hline
\end{tabular}

Source: Researcher's field survey, 2013.

\subsection{Species Frequency}

\subsubsection{Species Distribution in the Cultivated Areas of the Park}

From the result presented on Table 2 to Table 4, in the cultivated area, the area around the buffer had 18 species with 109 tree/shrub species within the plots (Table 2). The dominant species was Musanga cercropoides which constituted 20.2 percent of the total trees in the area. This was followed by Bateria nitrigiana which occupied $10.1 \%$ of the total species in the plots. Tectona grandis and Hylonendron gabonensis were the least constituting $0.9 \%$ each. Moreover, Musanga cercropoides has the highest Girth (diameter at breast Height (DBH) of $26.3 \mathrm{~cm}$ in average and a total Girth of $578.6 \mathrm{~cm}$ while Terminalia ivorensis followed with an average DBH of $20.5 \mathrm{~cm}$ and a total DBH of $41 \mathrm{~cm}$ (Table 2).

At the middle part of $100 \mathrm{~m}$ away from the buffer, 12 species with a total of 47 tree/shrubs were found. The dominant species being Terminalia ivorensis (17.0\%) of the plots but Melicia excelcia has the highest Girth of $47.1 \mathrm{~m}$. Terminalia ivorensis has the highest total DBH of $225.6 \mathrm{~cm}$ the least of the species Elaeis guinensis and Hylonendron gabonensis occupy $2.1 \%$ each (Table 3 ).

The third plots at inner portion contain 10 species with a total of 51 trees. Terminalia ivorensis dominates constituting $23.5 \%$ of the total species in the inner plots. Carcinia mannii occupy the $2^{\text {nd }}$ position $(13.7 \%)$ of the total species, Klanneidoxia gabonensis was the least with (2.0\%). Terminalia has the highest DBH of $386.4 \mathrm{~cm}$, however, Ceiba Petendra has the highest average DBH of $42.1 \mathrm{~cm}$ (Table 4).

\subsubsection{Species Distribution in the Fallow/Secondary Regrowth}

At the areas bounded by fallow, Musanga cercropoides dominates the outer plots and occupies $21.5 \%$ of the total species just as what was obtainable in the cultivated area (Table 5). This is followed by Anthocleista djalonensis (12.3\%) of the total species as against Bateria nitrigiana in the cultivated area. Tetrapleura tetraptera has the highest average DBH of $33.8 \mathrm{~cm}$. In the middle plot, Harugana madagascariensis and Upacea guinensis dominates (14.3\%) each. Melicia excelsia has the highest average DBH of $30.6 \mathrm{~cm}$ (Table 6). The inner plot contains 12 species and 42 trees, the dominant specie is Terminalia ivorensis, followed by Brachystegia Eurycoma (11.9\%) (Table 7).

Comparing the Biodiversity indices across the park, the number of species generally decreases inwards. Figure 2 shows the increase in number of species at the cultivated zone, while Figure 3 indicates that of the fallow zone. In both cases similar situation is obtained. However, the outer part on the edge of the park is dominated by shrubs and colonizers such as Musanga cercropoides, while at the middle and inner part dominated by Terminalia ivorensis which is the primary species. In the two areas, Musanga cercropoides dominates the outer plot at the buffer zone. Musanag cercroppoides is a colonizer and therefore shows sign of secondary regrowth. 
Table 2. Species distribution in the buffer area of the cultivated zones of the park.

\begin{tabular}{|c|c|c|c|c|}
\hline Species & Frequency & Percentage & Total Girth & Average Girth \\
\hline Alchornea cordifolia & 2 & 1.8 & 16.8 & 8.4 \\
\hline Ancistrophylum secondiflorum & 4 & 3.7 & 40.8 & 10.2 \\
\hline Anthocleista vogelli & 8 & 7.3 & 52.8 & 6.6 \\
\hline Bateria nitrigiana & 11 & 10.1 & 134.2 & 12.2 \\
\hline Carapa procera & 2 & 1.8 & 36 & 18 \\
\hline Dyopspyros spp & 3 & 2.8 & 36.9 & 12.3 \\
\hline Elaeis guinensis & 9 & 8.3 & 189 & 21 \\
\hline Funtumia africana & 3 & 2.8 & 57 & 19 \\
\hline Hylonendron gabonesis & 1 & 0.9 & 10 & 10 \\
\hline Musanga cerciopoides & 22 & 20.2 & 578.6 & 26.3 \\
\hline Pycanthus angolensis & 2 & 1.8 & 22 & 11 \\
\hline Randia acuminata & 8 & 7.3 & 71.2 & 8.9 \\
\hline Rauvolvia vomitoria & 9 & 8.3 & 55.8 & 6.2 \\
\hline Spondias mombin & 7 & 6.4 & 91 & 13 \\
\hline Tectona grandis & 1 & 0.9 & 25 & 25 \\
\hline Terminalia ivorensis & 2 & 1.8 & 41 & 20.5 \\
\hline Tetrapleura tetraptera & 3 & 2.8 & 66 & 22 \\
\hline \multirow[t]{2}{*}{ Theobroma сосао } & 12 & 11.0 & 242.4 & 20.2 \\
\hline & 109 & 100.0 & & \\
\hline
\end{tabular}

Source: Author’s Fieldwork, 2014.

Table 3. Species distribution within the middle part of the cultivated zone of the park.

\begin{tabular}{lcccc}
\multicolumn{1}{c}{ Species } & Frequency & Percentage & Total Girth & Average Girth \\
\hline Musanga cerciopoides & 3 & 6.4 & 48 & 16 \\
Poga Oleosa & 5 & 10.6 & 58.5 & 11.7 \\
Carcinia manii & 6 & 12.8 & 94.8 & 15.8 \\
Terminalia Ivorensis & 8 & 17.0 & 225.6 & 28.2 \\
Pentaclethra macrophyla & 3 & 6.4 & 55.2 & 18.4 \\
Randia acuminata & 4 & 8.5 & 189.2 & 16.1 \\
Melicia excelsa & 4 & 8.5 & 42.6 & 47.3 \\
Pycanthus angolensis & 2 & 4.3 & 166 & 21.3 \\
Carapa procera & 5 & 10.6 & 18.9 & 33.2 \\
Hylonendron gabonesis & 1 & 2.1 & 18.9 & 18.9 \\
Elaies guinensis & 1 & 2.1 & 119.5 & 18.9 \\
Uapaca guinenesis & 5 & 10.6 & & 23.9
\end{tabular}

Source: Author’s Fieldwork, 2014. 
Table 4. Species distribution within the inner part of the cultivated zone of the park.

\begin{tabular}{lcccc}
\hline \multicolumn{1}{c}{ Species } & Frequency & Percentage & Total Girth & Average Girth \\
\hline Brachystegia eurycoma & 4 & 7.8 & 104 & 26 \\
Carcinia manii & 7 & 13.7 & 83.3 & 11.9 \\
Ceiba petendra & 5 & 9.8 & 210.5 & 42.1 \\
Klaneidoxia gabonensis & 1 & 2.0 & 28 & 28 \\
Melicia excelsa & 3 & 5.9 & 110.4 & 36.8 \\
Poga Oleosa & 4 & 7.8 & 78.4 & 19.6 \\
Sacoglottis gabonensis & 5 & 9.8 & 386.4 & 23.1 \\
Terminalia Ivorensis & 12 & 23.5 & 166 & 32.2 \\
Tetrapleura tetraptera & 4 & 7.8 & 217.8 & 41.5 \\
Uapaca guinenesis & 6 & 11.8 & & 36.3 \\
\hline
\end{tabular}

Source: Author's Fieldwork, 2014.

Table 5. Species distribution within the buffer of the fallow zone of the park.

\begin{tabular}{lcccc}
\hline \multicolumn{1}{c}{ Species } & Frequency & Percentage & Total Girth & Average Girth \\
\hline Ancistrophylum secondiflorum & 5 & 7.7 & 31 & 6.2 \\
Anthocleista djalonensis & 8 & 12.3 & 59.2 & 7.4 \\
Bateria nitrigiana & 5 & 7.7 & 65 & 13 \\
Carapa procera & 4 & 6.2 & 96.8 & 24.2 \\
Elaeis guinensis & 5 & 7.7 & 134 & 26.8 \\
Funtumia africana & 1 & 1.5 & 32 & 32 \\
Magnifera indica & 2 & 3.1 & 62.8 & 31.4 \\
Musanga cerciopoides & 14 & 21.5 & 19.2 & 20.6 \\
Pycanthus angolensis & 2 & 3.1 & 33.6 & 9.6 \\
Randia acuminata & 4 & 6.2 & 37.2 & 8.4 \\
Rauvolvia vomitoria & 6 & 9.2 & 34.8 & 6.2 \\
Spondias mombin & 4 & 6.2 & 101.4 & 8.7 \\
Tetrapleura tetraptera & 3 & 4.6 & 59.6 & 33.8 \\
Terminalia Ivorensis & 2 & 3.1 & & 29.8 \\
\hline
\end{tabular}

Source: Author's Fieldwork, 2014.

Table 6. Species distribution within the middle area of the fallow zone of the park.

\begin{tabular}{|c|c|c|c|c|}
\hline Species & Frequency & Percentage & Total Girth & Average Girth \\
\hline Poga Oleosa & 5 & 10.2 & 58 & 11.6 \\
\hline Carcinia manii & 2 & 4.1 & 19.4 & 9.7 \\
\hline Terminalia Ivorensis & 6 & 12.2 & 178.8 & 29.8 \\
\hline Pentaclethra macrophyla & 4 & 8.2 & 64 & 16 \\
\hline Naudea didenidii & 4 & 8.2 & 68.8 & 17.2 \\
\hline Baphia nitida & 1 & 2.0 & 12 & 12 \\
\hline Melicia excelsa & 3 & 6.1 & 91.8 & 30.6 \\
\hline Pycanthus angolensis & 4 & 8.2 & 60 & 15 \\
\hline Harugana madagascariensis & 7 & 14.3 & 89.6 & 12.8 \\
\hline Carapa procera & 4 & 8.2 & 104 & 26 \\
\hline Hylonendron gabonesis & 2 & 4.1 & 43 & 21.5 \\
\hline \multirow[t]{2}{*}{ Uapaca guinenesis } & 7 & 14.3 & 182 & 26 \\
\hline & 49 & 100.0 & & \\
\hline
\end{tabular}

Source: Author's Fieldwork, 2014. 
Table 7. Species distribution within the inner area of the fallow zone of the park.

\begin{tabular}{lcccc}
\hline \multicolumn{1}{c}{ Species } & Frequency & Percentage & Total Girth & Average Girth \\
\hline Bailonella toxisperma & 1 & 2.4 & 27 & 27 \\
Brachystegia eurycoma & 5 & 11.9 & 88 & 17.6 \\
Sacoglottis gabonensis & 2 & 4.8 & 48.8 & 24.4 \\
Carapa procera & 2 & 4.8 & 56.6 & 28.3 \\
Irvingia gabonensis & 3 & 7.1 & 111.6 & 37.2 \\
Lophira alata & 4 & 9.5 & 80.4 & 20.1 \\
Naudea didenidii & 4 & 9.5 & 23.2 & 5.8 \\
Pentaclethra macrophyla & 4 & 9.5 & 40.8 & 10.2 \\
Pterocarpus spp & 3 & 7.1 & 54 & 18 \\
Terminalia Ivorensis & 8 & 19.0 & 230.4 & 28.8 \\
Tetrapleura tetraptera & 2 & 4.8 & 52.8 & 26.4 \\
Uapaca guinenesis & 4 & 9.5 & 119.6 & 29.9 \\
& $\mathbf{4 2}$ & $\mathbf{1 0 0 . 0}$ & &
\end{tabular}

Source: Author’s Fieldwork, 2014.

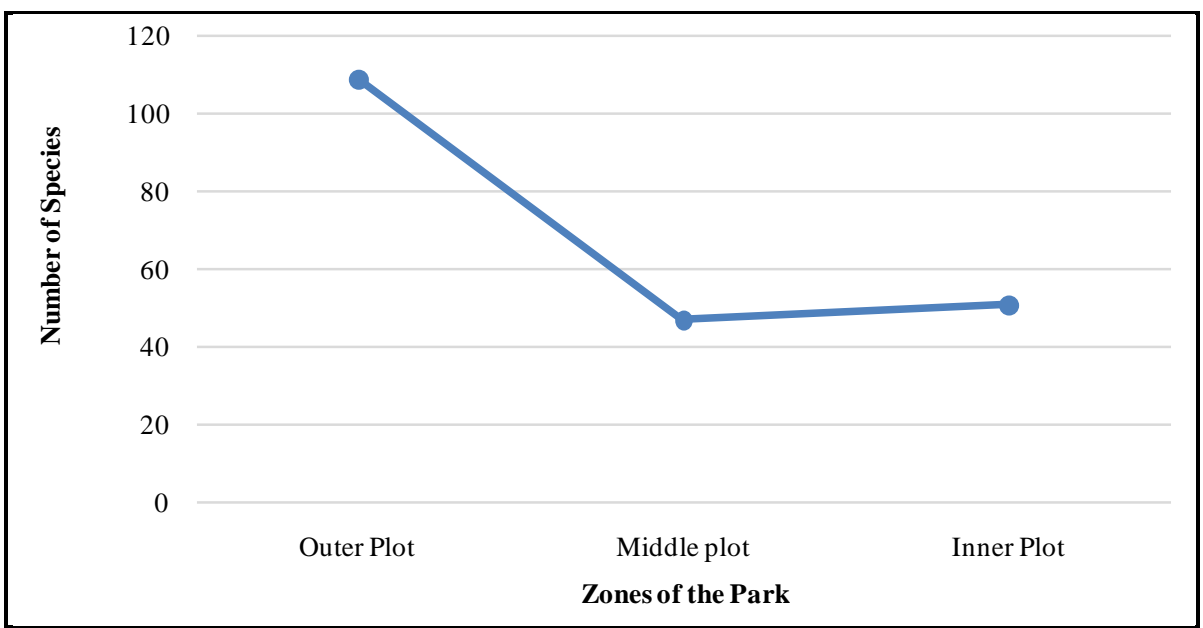

Figure 2. No. of species from outer to inner part of the cultivated zone.

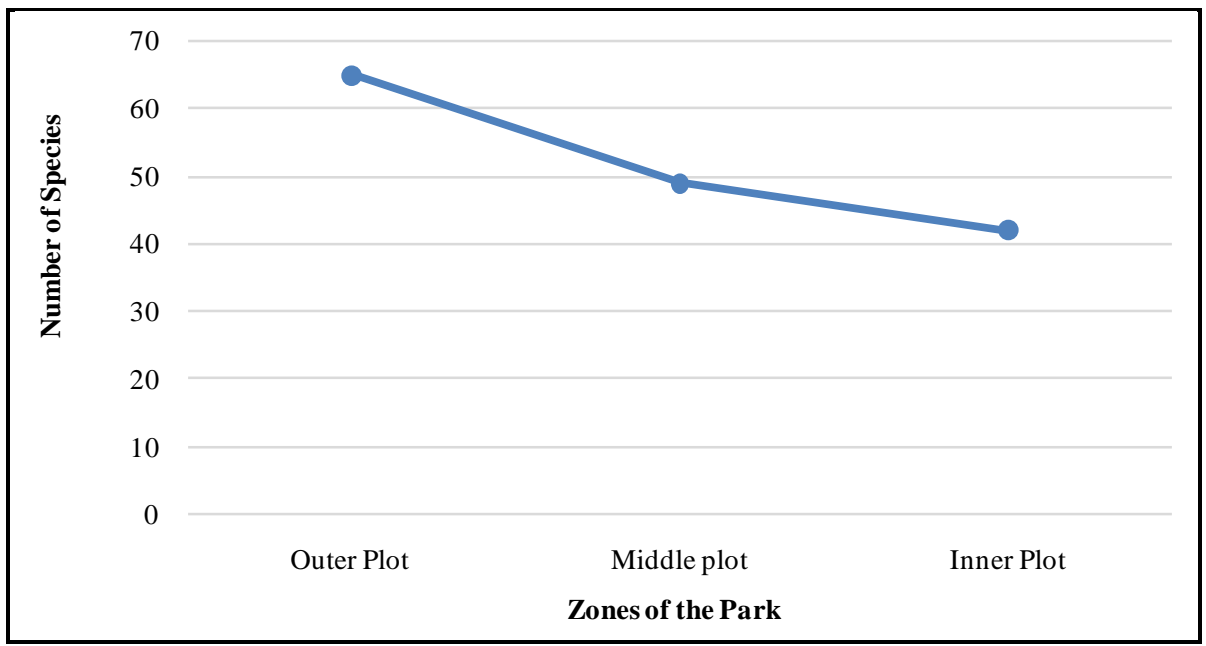

Figure 3. No. of species from the outer to inner part of the fallow zone. 


\subsection{Species Diversity}

Moreover, species diversity decreases from the outer part of the park inward the outer part has a diversity index of 2.566, at the middle part diversity decreases to 2.348 while at the inner part diversity further decreases to 2.163 (Table 8).

At the fallow areas, diversity also decreases inward from 2.443 at the outer part to 2.376 in the middle part. This further decreases to 2.366 (Table 8).

Diversity is higher at the outer part of the cultivated area than that of the secondary regrowth, whereas at middle and inner part diversity is higher at the secondary regrowth than that at the cultivated (Table 8).

\subsection{Discussion of Findings}

It is evident that the park area bounded by farms has undergone changes in species. For instance secondary colonizer such as Musanga cerciopoides which dominates both the cultivated area being 20.2 percent of the total species and 21.5 percent at the fallow zone, Bateria nitrigiana and other shrubs also dominate the outer zone of the park. Thus a reduction on primary tree species can occur. This corroborates studies by LUCID group on land change [14] [15] which shows that human activities affect land use which has changed to more cultivated area and less bush, forests and grasslands. These changes have often affect areas with natural vegetation where in some areas colonizers (mostly shrubs) colonize the area earlier occupied by natural vegetation. From the focus group discussion, the primary forest serves as areas for extraction of Non-Timber Forest products (NTFPs) while some undergo conversion from natural vegetation to cultivation of cocoa, the presence of Theobroma cocoa in the outer plot which constitute 11.0 percent of the total trees species in the area point to the fact that encroachment has taken place at the area bordering the buffer zone of the park especially at the cultivated area.

Moreover, Species diversity decreases as one move inward into the park. This is also due to the presence of shrubs at the outer part of the park. Land cover change through agricultural intensification and other diverse human activities has negative effect on the forest. Populations have often adapted to less than ideal conditions and represent an important genetic reservoir for long-term survival of species. From the FGD, it is observed that the park are threatened by illegal logging, encroachment, bush burning, farming, poaching and other human activities. The introduction of exotic species, over-harvesting of biodiversity resources, homogenization of species in agriculture, high energy consumption such as fuel wood, illegal hunting, and the drive habitat loss and species extinction worldwide [16]. The implication of the losses is the reduction in ecosystem services such as moderation of climate [17]-[23].

Tree species existing at edges of the forest normally faced degradation and are decimated to lesser and isolated species especially close to agro-ecosystems. Ecosystem alteration usually affect the survival of species, those that cannot survive in the new condition pave way for exotic species. One of the problems associated with species extinction is that of increase utilization of the species. Trees sequester carbon cutting down trees with huge girth means increasing the concentration of carbon in the atmosphere. The trees on the outer part have smaller girth which translates into reduction in biomass and increase emission of carbon, thus affecting climate change. Egbe et al. (2014) [24] envisage that one of the adaptive mechanism is increasing the biomass of trees through encouraging conservation [25] [26].

\section{Conclusion}

The values of biodiversity cannot be over-emphasized. The increasing human activities at the edge of the parks

Table 8. Species diversity within the different zones.

\begin{tabular}{ccc}
\hline & Species Diversity & \\
\hline Zones & Cultivated Area & Fallow Area \\
\hline Outer Plot & 2.57 & 2.44 \\
Middle plot & 2.35 & 2.38 \\
Inner Plot & 2.16 & 2.37 \\
\hline
\end{tabular}

Source: Author’s Fieldwork, 2014. 
have impacted on the distribution of species. This may have a cumulative effect in the near future for plants and animals at the primary forest. The increased colonization by shrubs and other alien species may continue to intrude into the inner part of the park. Cultivation close to the park continues to shift into the park altering species diversity. Resource exploitation is an important cause of biodiversity loss. For example, the demand for fuel wood and other forms of energy and natural resources consumption drive habitat conversion and changes to ecosystems components. However, communities can take to conservation and on the other hand use resources sustainably. It has been confirmed that indigenous and multiple-use protected areas can reduce the incidence of undue species loss.

\section{Recommendations}

With the increased colonization of the outer part of the park by alien species, it is therefore recommended that:

1) The boundary of the park and that of the buffer zone should be clearly demarcated and protected;

2) Biodiversity conservation should be integrated into the national and local economic planning, especially in the agricultural transformation agenda of federal government;

3) Monitoring programmes should be instituted for biodiversity;

4) Incentives and alternative means of livelihood should be given to the communities at the edge of the park that are still depending on the park for their livelihood to avoid impact on biodiversity.

\section{References}

[1] Vreugdenhil, D., Terborgh, J., Cleef, A.M., Sinitsyn, M., Boere, G.D., Archaga, V.L. and Prins, H.H.T. (2003) Comprehensive Protected Areas System Composition and Monitoring. WICE, Shepherdstown.

[2] Rotich, D. (2012) Concept of Zoning Management in Protected Areas. Journal of Environmental and Earth Science, 2, 173-183.

[3] CBD (2010) Global Biodiversity Outlook 3. Biological Diversity Programme of Work on Protected Areas, Secretariat of the Convention on Biological Diversity, Montreal, Technical Series No. 18, 108 p.

[4] Dudley, N., Bhagwat, S., Higgins-Zogin, L., Lassen, B., Verschuuren, B. and Wild, R. (2010) Conservation of Biodiversity in Sacred Natural Sites in Asia and Africa: A Review of the Scientific Literature. In: Verschuuren, B., Wild, R., McNeely, J. and Oviedo, G., Eds., Sacred Natural Sites, Conserving Nature and Culture, Earthscan, London, 19-32.

[5] Kamau, P. (2004) Forage Diversity and Impact of Grazing Management on Rangeland Ecosystems in Mbeere District, Kenya. LUCID Working Paper No. 36, International Livestock Research Institute, Nairobi.

[6] James, B. (2013) The Impact of Deforestation in Forest Livelihood. Centre for International Governance Innovation (CIGI), Ghana.

[7] Obong, L.B., Aniah, E.J., Okaba, L.A. and Effiom, V.A. (2013) Sustainable Livelihood in Cross River National Park (CRNP), Oban Division, Nigeria. International Journal of Business and Social Science, 4, 15-27.

[8] Eneji, C.V.O., Gubo, Q., Okpiliya, F.I., Aniah, E.J., Eni, D.D. and Afanghideh, D. (2009) Problems of Public Participation on Biodiversity Conservation: The Nigerian Scenario. Journal of Impact Assessment and Project Appraisal, 27, 301-307. http://dx.doi.org/10.3152/146155109X479431

[9] Eneji, C.V.O., Gubo, Q., Jian, X., Oden, S N. and Okpiliya, F.I. (2009) A Review of the Dynamics of Forest Resources Valuation and Community Livelihood: Issues, Arguments and Concerns. Journal of Agriculture, Biotechnology and Ecology, 2, 210-231.

[10] Gandiwa, P., Matsvayi, W., Ngwenya, M.M. and Edson, G. (2011) Assessment of Wildlife and Human Settlement Enccroachment into the Northern Gonarezhou National Park, Zimbabwe. Journal of Sustainable Development in Africa, 13, 19-33.

[11] Otu, J.E., Joseph, K.U. and Eja, E.I. (2011) Impact of Population Growth on Forest Resources Degradation in Ikom Local Government Area. Department of Sociology, University of Calabar, Nigeria. Universal Journal of Management and Social Sciences, 1, 1-11.

[12] Bisong, F.E. and Mfon, P. (2006) Effect of Logging on Stand Damage in the Rainforest of South-Eastern Nigeria. West African Journal of Applied Ecology, 10, 1-10.

[13] Eniang, E.A. and Ijeomah, H.M. (2011) Diversity of Ophidian Species in Oban Division of the Cross River National Park, Nigeria. PAT 2011, 7, 188-201.

[14] Mugisha, S. (2002) Root Causes of Land Cover/Use Change in Uganda: An Account of the Past 100 Years. LUCID Working Paper No.14, International Livestock Research Institute, Nairobi. http://www.lucideastafrica.org/ 
[15] Misana, S.B., Majule, A.E. and Lyaruu, H.V. (2003) Linkages between Changes in Land Use, Biodiversity and Land Degradation on the Slopes of Mount Kilimanjaro, Tanzania. LUCID Working Paper No. 38, International Livestock Research Institute, Nairobi.

[16] Hens, L. and Boon, I.E. (2003) Causes of Biodiversity Loss: a Human Ecological Analysis. http://www.multiciencia.unicamp.br/artigos_01/A1_HensBoon_ing.PDF

[17] MA (2005) Ecosystems and Human Well-Being: Synthesis. Millennium Ecosystem Assessment, World Resources Institute, Island Press, Washington DC.

[18] MA (2005) Ecosystems and Human Well-Being: Wetlands and Water Synthesis. Millennium Ecosystem Assessment, World Resources Institute, Island Press, Washington DC.

[19] Giraud, G. (2008) Range and Limit of Geographical Indication Scheme: The Case of Basmati Rice from Punjab, Pakistan. International Food and Agribusiness Management Review, 11, 51-76.

[20] UNEP (2007) Global Environment Outlook 4: Environment for Development. United Nations Environment Programme, Progress Press, Valletta.

[21] Horowitz, L. (1997) Encroachment on Protected Areas by Small-Scale Actor: An Examination of the Issues. Conservation International, Washington DC.

[22] TEEB (2010) The Economics of Ecosystems and Biodiversity: Mainstreaming the Economics of Nature: A Synthesis of the Approach, Conclusions and Recommendations of TEEB. The Economics of Ecosystems and Biodiversity, Progress Press, Malta.

[23] Nelson, A. and Chomitz, K.M. (2011) Effectiveness of Strict vs. Multiple Use Protected Areas in Reducing Tropical Forest Fires: A Global Analysis Using Matching Methods. PLoS ONE, 6, e22722. http://dx.doi.org/10.1371/journal.pone.0022722

[24] Egbe, C.A., Yaro, M.A., Okon, A.E. and Bisong, F.E. (2014) Rural Peoples’ Perception to Climate Variability/Change in Cross River State-Nigeria. Journal of Sustainable Development, 7, 25-36. http://dx.doi.org/10.5539/jsd.v7n2p25

[25] Kinzig, A.P., Perrings, C., Chapin, F.S., Polasky, S., Smith, V.K., Tilman, D., et.al. (2012) Ecosystem Services: Free Lunch No More Response. Science, 335, 656-657. http://dx.doi.org/10.1126/science.335.6069.656-b

[26] Dudley, N., Mulongoy, J., Cohen, S., Stolton, S., Barber, C.V. and Gidda, S.B. (2005) Towards Effective Protected Area Systems. An Action Guide to Implement the Convention on Biological Diversity Programme of Work on Protected Areas. Secretariat of the Convention on Biological Diversity, Montreal, Technical Series No. 18.

https://www.cbd.int/doc/publications/cbd-ts-18.pdf 